\title{
Physico chemical analysis of Kandhaga Rasayanam, a Siddha herbomineral formulation
}

\author{
${ }^{1,}$ Dr.Meena .R , ${ }^{2,}$ Dr. Ramaswamy. RS , ${ }^{3,}$ Shakila. R \\ ${ }^{1 .}$ PhD Research scholar, Sirappu Maruthuvam Department, National Institute of Siddha, Chennai \\ 2 .Director General , CCRS, Arumbakkam, Chennai \\ ${ }^{3 .}$ Research office,Department of chemistry,SCRI,Arumbakkam.
}

\begin{abstract}
:
BACKGROUND : Standardization of AYUSH drugs is the need of the hour. Kandhaga rasayanam is a Siddha herbo mineral drug indicated for skin diseases, urinary infections.
\end{abstract}

AIM AND OBJECTIVE : To do physicochemical analysis for the drug Kandhaga rasayanam

MATERIALS AND METHODS: The drug is prepared as per the methods mentioned the classic siddha literature.The drug is subjected to physicochemical analysis such as total ash, loss on drying, total sugar, reducing sugar, fat content, microbial load, heavy metal analysis, Thin Layer Chromatography and High Performance Thin Layer Chromatography as per the Pharmacopeial laboratory standards of Indian medicine.

RESULTS AND CONCLUSION:The drug is free of microbial contamination and shows positive for the presence of alkaloids, tannins, phenols, steroids, saponins, anthraquinones, flavanoids etc.The total ash value is 2.0\%. The heavy metals such as lead, arsenic, mercury, cadmium are below detectable limit.

Key words: Herbomineral , High Performance Thin Layer Chromatography, Physico chemical Analysis, Phytochemistry, Siddha.

\section{INTRODUCTION:}

Recently the entire population is showing interest in traditional medicine and it has increased the demand for Siddha drugs.Siddha system of medicine is one of the ancient system of medicine. Siddhars, the great scientists of olden age are the founders of this system. Kandhaga rasayanam is a classic Siddha drug chosen from the text Siddha Vaidhya Thirattu. It is indicated for skin diseases, urinary tract infections, venereal diseases,diarrohoea piles, peptic ulcer and arthritis. ${ }^{1}$ The use of scientific tools are essential to validate the traditional claim. Though Siddha drugs are considered to be safe and effective, it is the utmost duty of the physicians to standardize the formulation before trying out in humans. The drug is a herbomineral drug with sulphur as the sole mineral ingredient. The remaining ingredients are herbs. The main aim of this study is to evaluate the physico chemical characters of the drug Kandhaga rasayanam.

\section{AIM AND OBJECTIVE :}

The aim of this study is to do phsico chemical analysis , HPTLC finger printing and preliminary phytochemistry for the drug Kandhaga rasayanam.

\section{Collection and Identification of plant materials:}

\section{MATERIALS AND METHODS:}

The mineral drug sulphur is identified and authenticated by the Research officer, Chemistry Department of SCRI, Chennai. The herbal ingredients were authenticated by the Assistant Professor of Medicinal botany Department of National Institute of Siddha, Chennai.The raw drugs were purified as per the methods mentioned in the literature.

3.2. Preparation of the drug Kandhaga rasayanam ${ }^{2}$ : Ingredients of the drug Kandhaga rasayanam are given below.

Kandhagam (Sulphur)

Amukkara kizhangu (Withania somnifera.Dunal,)

Parangi chakkai (Smilax china Linn.)

Kadukkai (Terminalia chebula. Retz.)

350 grams.

Nellikai (Phyllanthus emblica Linn.)

175 grams.

70 grams.

35 grams.

35 grams. 
Thandrikkai(Terminalia bellerica Roxb.)

Chukku (Zingiber officinale.Roscoe.)

Thippili moolam (root of Piper longum.Linn.)

Milagu (Piper nigrum.Linn.)

Vaividangam(Embelia ribes,Burm.)

Ealam(Elataria cardamomum.Linn.)

Kirambu (Cinnamomum zeylanicum.Breyn.)

Chandhanam (Santalum album,Linn)

Kadalai (cicer arietinum,Linn.)

Senkottai(Semecarpus anacardium. Linn.)

Chithiramoola verpattai(root bark of Plumbago zeylanica,Linn)

Sugar, Honey and Ghee.

The quantity of sugar, honey, and ghee is not prescribed. So, sufficient quantity is added.

\subsection{Purification of raw drugs ${ }^{3}$ :}

The raw drugs are purified as per the methods mentioned in the Siddha literatures .

\subsection{Chemicals :}

Solvents and chemicals of analytical grade were procured from E. Merck and S.D. fine chemicals, Mumbai. DA.

\subsection{Analytical specifications of semisolid drugs 4 .}

1..Description : Colour, Odour, Taste, 2. Loss on drying at $1050 \mathrm{C}, 3$. Total - ash, 4. Acid - insoluble ash, 5. pH, 6. Total solid, 7. Fat content, 8. Reducing sugar,9. Total sugar, 10. Identifications : TLC/HPTLC, 11 Test for heavy metals: Lead, Cadmium,Mercury, Arsenic, 12. Microbial contamination: Total bacterial count,Total fungal count, 13. Test for specific Pathogen: E. coli, Salmonella spp., S.aureus, Pseudomonas aeruginosa,

14. Pesticide residue: Organochlorine pesticides, Organophosphorus pesticides, 15 Test for Aflatoxins (B1,B2,G1,G2).

\subsection{Thin Layer Chromatography Conditions:}

3.6.1.Sample Preparation: $4 \mathrm{~g}$ of the drug was first defatted with hexane and then soaked overnight in chloroform. Boiled on a water bath for $10 \mathrm{mins}$, filtered and concentrated to $10 \mathrm{ml}$.

3.6.2. Solvent system: Toluene : Ethyl acetate (4:1.5).

3.6.3.TLC plate: Aluminium plate precoated with silica gel $60 \mathrm{~F}_{254}$ of $0.2 \mathrm{~mm}$ thickness (Merck).

3.6.4.Developing chamber: Camag's twin trough chamber.

3.6.5.Visualizing reagent: Vanillin-sulphuric acid reagent.

3.6.6.Procedure: The extract was applied on the TLC plate using applicator and developed in the solvent system. The developed TLC plate was air dried, viewed under UV $254 \mathrm{~nm}, 366 \mathrm{~nm}$ and then dipped in vanillin-sulphuric acid reagent and heated in an oven at $105^{\circ} \mathrm{C}$ until the development of coloured spots.further HPTLC analysis was done.All the physicochemical parameters were carried out as per WHO guidelines (Anonymous. 1998. Quality Control Methods for Medicinal Plant Materials, World Health Organisation, Geneva.)

\subsection{Physicochemical analysis ${ }^{5}$ :}

The sample is tested for the following parameters as per the guidelines followed by WHO. Loss on drying , Total ash, Water soluble ash, Acid insoluble ash, Water soluble extractive , Alcohol soluble extractive, Fat content, Reducing sugar, Total sugar, Microbial load Aflatoxins and Heavy metaqls.

\subsection{Preliminary Phytochemical Tests ${ }^{6,7}$ :}

Preliminary Phytochemical tests such as test for Proteins (Biuret test), Steroids (Lieberman Burchard Test) , Flavonoids (Shinoda test) , Triterpenoids (Noller's Test) ,Phenol , Tannin , Alkaloids (Dragendorff's Test) , Glycosides , Cardiac glycoside (Keller-Killani Test) ,Reducing sugar (Fehling's Test), Saponins were carried out. 


\section{RESULTS AND DISCUSSION:}

4.1.Organoleptic characters:

Colour- blackish brown.

Odour - characteristic

Taste : sweet, pungent.

Consistency- semisolid

The characteristic odour is due to the presence of sulphur. The sweet taste and semisolid consistency is due to the addition of sugar, ghee and honey.

\subsection{Physico-Chemical Parameters:}

The results of the physicochemical parameters are given in Table 1 .

TABLE 1: Results of physicochemical parameters:

\begin{tabular}{|c|c|c|c|c|c|}
\hline S.No & Parameter & & I & II & Mean \\
\hline 1. & Loss on Drying at $105^{\circ} \mathrm{C}$ & : & $14.833 \%$, & $16.321 \%$ & $15.577 \%$ \\
\hline 2. & Total Ash & : & $2.01 \%$ & $1.99 \%$ & $2.0 \%$ \\
\hline 3. & Water soluble Ash & $:$ & $1.097 \%$, & $0.995 \%$, & $1.046 \%$ \\
\hline 4. & Acid insoluble Ash & $:$ & $0.186 \%$ & $0.171 \%$ & $0.179 \%$ \\
\hline 5. & Water Soluble Extractive & : & $52.825 \%$ & $53.839 \%$, & $53.331 \%$ \\
\hline 6. & Alcohol Soluble Extractive & : & $50.706 \%$ & $49.932 \%$ & $50.319 \%$ \\
\hline 7. & Fat Content & : & $4.621 \%$, & $4.563 \%$ & $4.592 \%$ \\
\hline 8. & Reducing Sugar & : & $6.7 \%$, & $6.3 \%$, & $6.5 \%$ \\
\hline 9. & Total Sugar & : & $26.6 \%$ & $25.6 \%$ & $26.1 \%$ \\
\hline
\end{tabular}

Loss on drying indicates the moisture content . The total ash content is the measure of inorganic constituents present in the drug. High ash content explains its unsuitable nature to be used as drug.

\subsection{Heavy metal analysis using ICPOES:}

the observed results of heavy metal analysis is tabulated below in table 2 .

TABLE 2 : Results of heavy metal analysis:

\begin{tabular}{|l|l|l|}
\hline Heavy Metal & $\begin{array}{l}\text { Specification as per } \\
\text { AYUSH/WHO/FDA(26...) }\end{array}$ & Observed Result \\
\hline Lead & $10 \mathrm{ppm}$ & BDL(D.L-0.05PPM) \\
\hline Cadmium & $0.3 \mathrm{ppm}$ & BDL(D.L-0.05PPM) \\
\hline Arsenic & $3.0 \mathrm{ppm}$ & BDL(D.L-0.05PPM) \\
\hline Mercury & $1 \mathrm{ppm}$ & BDL(D.L-0.01PPM) \\
\hline
\end{tabular}


The heavy metals such as lead, cadmium, arsenic and mercury are found below detectable limit.

\subsection{Test for Aflatoxins and Pesticide Residues:}

TABLE 3: Results of test for Aflatoxins and Pesticide Residues:

\begin{tabular}{|c|c|}
\hline Test & Observed Result \\
\hline Aflatoxin B1 & 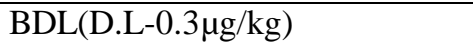 \\
\hline Aflatoxin B2 & 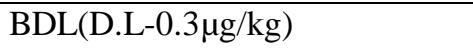 \\
\hline Aflatoxin G1 & 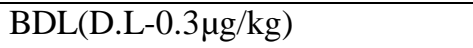 \\
\hline Aflatoxin G2 & 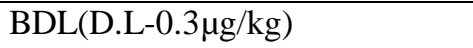 \\
\hline Organophosphorus & Not detected (D.L: $0.005 \mathrm{MG} / \mathrm{kg}$ ) \\
\hline Organochloride & Not detected (D.L: $0.005 \mathrm{MG} / \mathrm{kg}$ ) \\
\hline
\end{tabular}

\subsection{Test for Bacterial and Fungal count:}

TABLE 4: Results of test for bacterial and fungal count:

\begin{tabular}{|l|l|l|}
\hline Test & $\begin{array}{l}\text { Specification as per } \\
\text { AYUSH/WHO/FDA }\end{array}$ & Observed Result \\
\hline Total bacterial count & NMT $105 \mathrm{CFU} / \mathrm{g}$ & $<10 \mathrm{CFU} / \mathrm{g}$ \\
\hline Total fungal count & NMT $103 \mathrm{CFU} / \mathrm{g}$ & $<10 \mathrm{CFU} / \mathrm{g}$ \\
\hline E.coli & Absent/g & Absent/g \\
\hline Salmonella & Absent/g & Absent/g \\
\hline Pseudomonas aeruginosa & Absent/g & Absent/g \\
\hline Staphyloccus aureus & Absent/g & \\
\hline
\end{tabular}

The bacterial and fungal load are within the prescribed limits. The above results suggests that the prepared drug Kandhaga rasayanam is of standard quality.

\subsection{Phytochemical Tests:}

TABLE 5 : Results of physicochemical analysis:

\begin{tabular}{|l|l|l|}
\hline Sl. No & Name of the Test & Result \\
\hline 1. & Test for Amino acids (Biurette test) & $+\mathrm{ve}$ \\
\hline 2. & Test for Steroid (Lieberman Burchard Test) & $+\mathrm{ve}$ \\
\hline 3. & Test for Flavonoids (Shinoda test) & $+\mathrm{ve}$ \\
\hline 4. & & $+\mathrm{ve}$ \\
\hline
\end{tabular}


Physico Chemical Analysis...

\begin{tabular}{|l|l|l|}
\hline 5. & Test for Phenol & $+\mathrm{ve}$ \\
\hline 6. & Test for Tannin & $+\mathrm{ve}$ \\
\hline 7. & Test for Alkaloids (Dragendorff's Test) & $+\mathrm{ve}$ \\
\hline 8. & Test for Glycosides & $+\mathrm{ve}$ \\
\hline 9. & Test for Saponins & $+\mathrm{ve}$ \\
\hline 10. & Test for Anthraquinones & $+\mathrm{ve}$ \\
\hline
\end{tabular}

The above table shows the presence of all secondary metabolites. Their presence indicates the antioxidant, antimicrobial, ant iallergic, antifungal, anti-inflammatory property of the drug. its clinical use is thus validated.

A TLC profile is done for the drug Kandhaga rasayanam. The TLC image is shown in Figure1.

The.$R_{f}$ values are given in table 6.The HPTLC peaks are given in Figure 2.

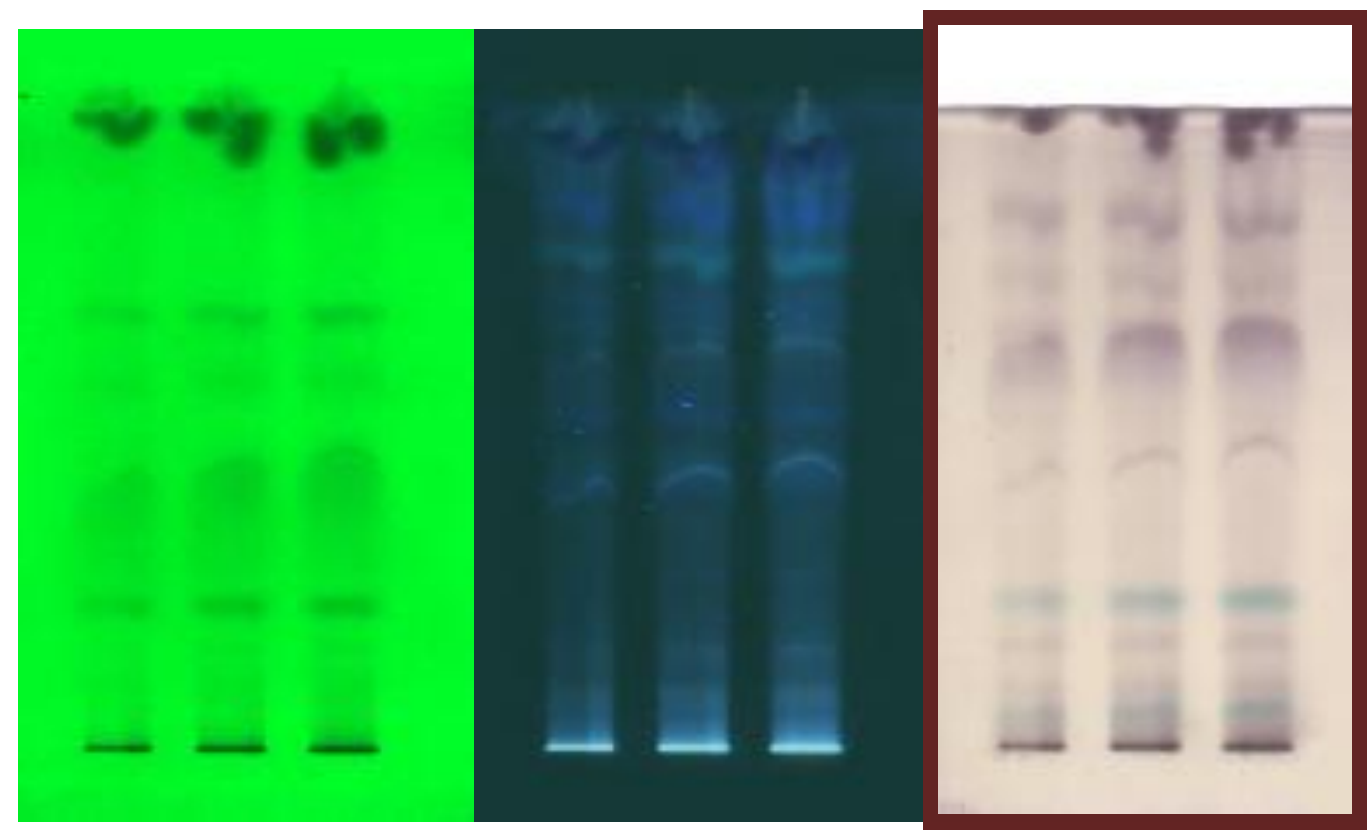

Under UV $254 \mathrm{~nm} \quad$ UV $366 \mathrm{~nm}$

After spray with VSR

Figure $1::$ TLC profile of chloroform extract of defatted Kanthaga Rasayanam

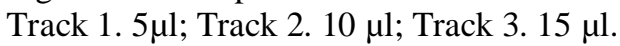

TABLE $6:$. $\mathrm{R}_{\mathrm{f}}$ values and Colour of spots under pre and post derivative conditions

\begin{tabular}{|l|l|l|c|l|c|l|}
\hline \multirow{2}{*}{ Sl.No } & \multicolumn{2}{|l|}{ Under UV 254 nm } & \multicolumn{2}{l|}{ Under UV 366 nm } & \multicolumn{2}{l|}{$\begin{array}{l}\text { After spray in Vanillin-Sulphuric } \\
\text { acid }\end{array}$} \\
\cline { 2 - 7 } & $\begin{array}{l}\mathrm{R}_{\mathrm{f}} \\
\text { value }\end{array}$ & $\begin{array}{l}\text { Colour of the } \\
\text { spot }\end{array}$ & $\begin{array}{l}\mathrm{R}_{\mathrm{f}} \\
\text { value }\end{array}$ & $\begin{array}{l}\text { Colour of the } \\
\text { spot }\end{array}$ & $\mathrm{R}_{\mathrm{f}}$ value & Colour of the spot \\
\hline 1 & 0.08 & Green & 0.15 & Blue & 0.08 & Greenish blue \\
\hline 2 & 0.15 & Green & 0.23 & Blue & 0.15 & Violet \\
\hline 3 & 0.23 & Green & 0.48 & Blue & 0.23 & Violet \\
\hline 4 & 0.41 & Green & 0.68 & Blue & 0.35 & Greenish blue \\
\hline 5 & 0.61 & Green & 0.78 & Blue & 0.48 & Violet \\
\hline 6 & 0.73 & Green & 0.88 & Blue & 0.68 & Violet \\
\hline 7 & - & - & - & - & 0.78 & Violet \\
\hline 8 & - & - & - & - & 0.88 & Violet \\
\hline
\end{tabular}




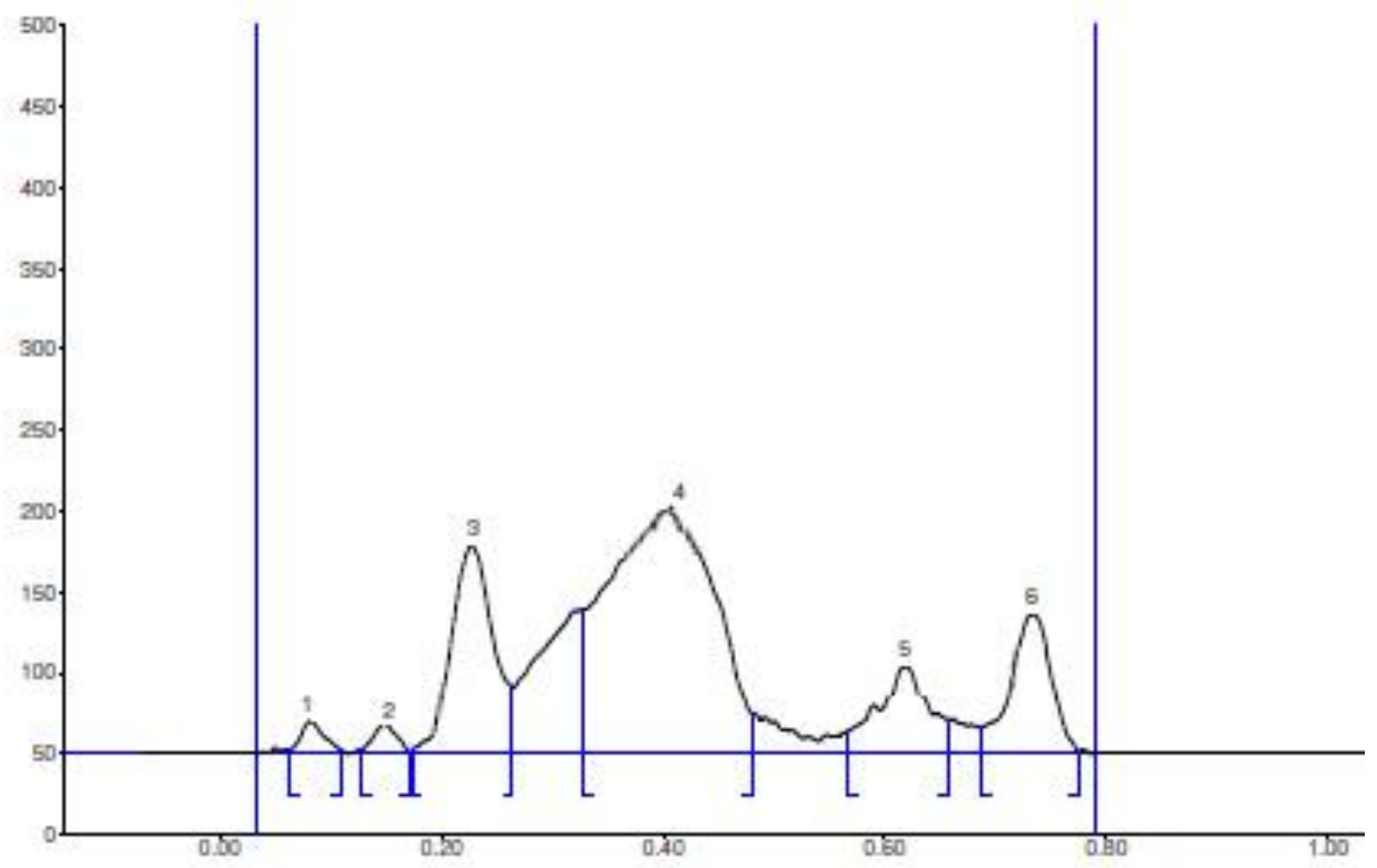

Figure 2: HPTLC Finger print profile of defatted chloroform extract of Kanthaga Rasayanam

$\mathrm{R}_{\mathrm{f}}$ and \% peak area of defatted chloroform extract of Kanthaga Rasayanam

\begin{tabular}{|cccccccccc|}
\hline Peak & $\begin{array}{c}\text { Start } \\
\text { Rf }\end{array}$ & $\begin{array}{c}\text { Start } \\
\text { Height }\end{array}$ & $\begin{array}{c}\text { Max } \\
\text { Rf }\end{array}$ & $\begin{array}{c}\text { Max } \\
\text { Height }\end{array}$ & $\begin{array}{c}\text { Max } \\
\text { \% }\end{array}$ & $\begin{array}{c}\text { End } \\
\text { Rf }\end{array}$ & $\begin{array}{c}\text { End } \\
\text { Height }\end{array}$ & \multicolumn{1}{c|}{ Area } & \multicolumn{1}{c|}{\begin{tabular}{c} 
Area \\
\hline
\end{tabular}} \\
\hline 1 & 0.04 & 3.5 & 0.08 & 20.9 & 5.07 & 0.11 & 6.4 & 532.5 & 2.41 \\
2 & 0.13 & 2.3 & 0.15 & 16.2 & 3.94 & 0.18 & 2.0 & 294.5 & 1.34 \\
3 & 0.18 & 2.5 & 0.23 & 118.9 & 28.84 & 0.26 & 35.1 & 3683.3 & 16.70 \\
4 & 0.33 & 70.4 & 0.44 & 134.9 & 32.73 & 0.53 & 3.3 & 13155.1 & 59.66 \\
5 & 0.56 & 7.0 & 0.62 & 42.4 & 10.29 & 0.66 & 17.5 & 1946.0 & 8.82 \\
6 & 0.68 & 12.8 & 0.73 & 78.9 & 19.13 & 0.77 & 0.2 & 2440.1 & 11.07 \\
& & & & & & & & & \\
\hline
\end{tabular}




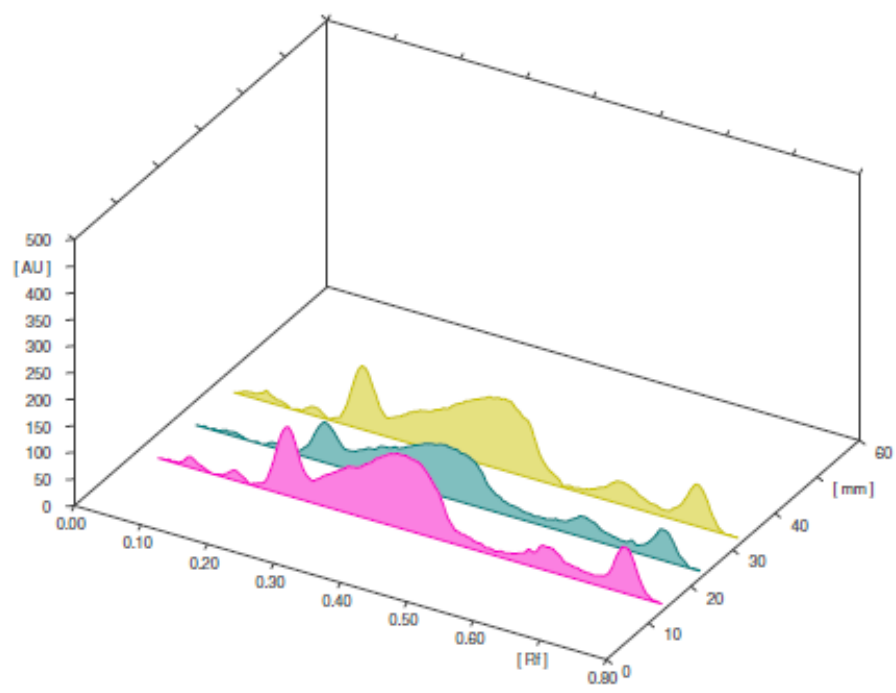

Figure:3 Chromatogram of all tracks of defatted chloroform extract of Kanthaga Rasayanam

\section{CONCLUSION:}

Based on the above results , it can be assumed that the drug Kandhaga rasayanam has validated the traditional claim.

\section{REFERENCES:}

[1] Dr.Kuppusamy mudhaliar, Dr.Utthamarayan,( Siddha Vaidhya Thirattu (Indian medicine and homoeopathy, Chennai-106,February 1998 ) 235.

[2] Dr.Kuppusamy mudhaliar, Dr.Utthamarayan,( Siddha Vaidhya Thirattu (Indian medicine and homoeopathy, Chennai-106,February $1998) 235$.

[3] Dr.R.Thyagarajan,(Gunapadam Thadhu Jeeva Vaguppu, Indian medicine and Homoeopathy, Chennai-106,Ed - 4 1992 ) 235.

[4] Dr.D.R.Lohar,(Pharmacopoeial laboratory for Indian medicine, Department of Ayurvedha, yoga and Naturopathy, Siddha, Unani and Homoeopathy ( AYUSH), Ministry of health and family welfare, 2011) 20.

[5] 13.Anonymous, (Quality control methods for medicinal plant materials, .WHO:Geneva; 1998, )

[6] JB( Phytochemical methods, Chapman and Hill, London 1973).

[7] Harbone Trease G.E and W.C.Evans,(pharmacognosy, Brailliar Tiridel and Macmillian Publishers, London Ed-11). 